\title{
Neoliberalism and Low-income Housing in Japan
}

\author{
Yosuke Hirayama ${ }^{1}$ \\ (Received December 24, 2012 / Revised January 28, 2013 / Accepted January 28, 2013)
}

\begin{abstract}
Over the past three decades, neoliberalism has been pervasive and even normative in reorganizing housing systems, encouraging a decline in low-income housing. However, the way in which neoliberal prescriptions have impacted on housing processes has not necessarily been the same but has rather differed according to the indigenous social, economic, political, and institutional contexts of particular countries. In the case of Japan, neoliberalization has effectively combined with a traditionally residualized public housing to affect housing circumstances surrounding low-income people. This article explores transformations in low-income housing in Japan to demonstrate the importance of specific housing contexts in particular societies, in terms of looking at the impact neoliberalism has had on housing processes.
\end{abstract}

Key words: Housing Policy, Neoliberalism, Low-income Housing, Public Housing, Japan

\section{Introduction}

Over the past three decades, neoliberalism has been pervasive and even normative in reorganizing housing systems, encouraging a decline in low-income housing. Governments in many industrial and post-industrial countries have increasingly directed housing policies towards accentuating the role of the market in providing and financing housing. This has led to the expansion of owner-occupied housing markets with reductions in the availability of social rented housing. However, the way in which neoliberal prescriptions have impacted on housing processes has not necessarily been the same but has rather differed according to the indigenous social, economic, political, and institutional contexts of particular countries.

Japan serves as a vivid exemplar with regards to how neoliberal policy has affected low-income housing. After the end of the Second World War, many developed countries, particularly European ones, steered themselves towards constructing more comprehensive welfare states, where governments formulated housing policies that were aimed at expanding social housing sectors. In contrast, since the immediate postwar period, Japan's housing policy has been focused on facilitating middle-class home ownership while directly providing public rented housing to low-income households has been significantly residualized (Harada, 1985; Hayakawa, 2002; Hirayama, 2003, 2007; Ohmoto, 1996). The ascendance of neoliberalism has been seen throughout many countries, leading to reductions in low-income housing. However, many European countries have sustained a considerable amount of social rented housing, reflecting the past trajectories of housing policies. Neoliberalization in Japan has effectively combined with a traditionally residualized public housing policy to erode the system of providing housing to those on low incomes.

This article explores transformations in low-income housing in Japan to demonstrate the importance of specific housing contexts in particular societies, in terms of looking at the impact neoliberalization has had on housing processes. Japan's economy has long been unstable, and this has undermined housing security. Immediately after the bubble economy collapsed at the beginning of the 1990s, Japan entered a noticeably prolonged period of recession characterized by minimal or negative real growth in GDP, rising unemployment rates, and reduced real incomes. Although the Japanese economy eventually began to recover in 2002, the economic upturn did not translate into an improved household economy. Moreover, Japan re-entered an enduring recession in 2008, after becoming entangled in the Global Financial Crisis triggered by the U.S. subprime mortgage meltdown. Subsequently, an additional strong blow was delivered to the nation's weakened economy by the major earthquake in Tohoku in 2011. Thus, economic stagnation since the early 1990s has come to be perceived as 'normal' rather than 'abnormal'. The introduction of neoliberal policy within the context of post-bubble

1) Professor, Housing and Urban Studies, Graduate School of Human Development and Environment, Kobe University (Corresponding author: yosukeh@kobe-u.ac.jp) 
recession was expected to stimulate economic recovery and the shift in housing policy towards market-based accommodation was assumed to improve the housing situation. Nevertheless, the economy has continued to decline while the marginalization of low-income housing policy has further increased insecurity with housing. This article begins by looking at changes in the Japanese low-income housing system, placing particular emphasis on its traditionally residual nature and the more recent employment of neoliberal prescriptions. This will be followed by detailed analyses of the decline in Japan's unique system of providing low-rent housing. Finally, the article explores transformations in the housing circumstances of low-income households.

\section{Traditionally residual}

Governments in many countries including Japan have reoriented housing policies towards a more neoliberal model. However, housing systems have assumed a path-dependent nature and therefore the diffusion of neoliberal prescriptions have interacted with the local housing contexts of particular societies to result in the diversification of housing transformations. This and the following sections highlight changes in Japan's housing system as a case in which neoliberal policy has further marginalized low-income housing that had traditionally been residual.

The housing system in postwar Japan has consistently driven the growth of the owner-occupied housing sector, where many households have successively ascended the housing ladder towards home ownership (Hirayama, 2003; 2007). The Government Housing Loan Corporation (GHLC) was established as a state agency in 1951 to provide many middle-class households with low-interest mortgages to acquire or construct their own homes. Of the various measures available through housing policy, the supply of GHLC mortgages was especially emphasized to promote middle-class home ownership. The level of owner-occupied housing since the 1960s has been maintained at approximately 60 per cent, retaining its position as the dominant housing tenure. The ratio of private rented housing has been the second highest, accounting for approximately a quarter of all housing. However, the government has not supported the supply of private rented housing. There has been little assistance to construct private rented housing and absolutely no provision of rental subsidies. The direct supply of rented housing by the public sector has been positioned as a residual measure. Public housing has been allocated to low-income households and public corporations have constructed rented housing for urban middle-income households. However, the ratios of low-income public housing and publiccorporation housing have been low, corresponding to approximately 4 per cent and 2 per cent. Japan's housing system has thus characteristically been tenure-discriminatory, where the government has led many middle-class households to climb the property ladder and has residualized rental housing policy.
The Japanese state, which has often been described as a developmental state, has prioritized and orchestrated economic expansion to legitimize itself and sustain social stability. The Liberal Democratic Party (LDP), a party of establishment conservatives, held power almost exclusively since it was founded in 1955 until 2009, when it lost the national elections. Within the framework of developmental state policy, LDP politicians and government bureaucrats accelerated the mass construction of owner-occupied housing as an engine for economic growth. Since 1966 when the Housing Construction Plan Law was enacted, a Five-Year Housing Construction Plan has been drawn up periodically as a foundation for housing policy. Under these plans the majority of subsidy for housing construction has taken the form of GHLC loans. The LDP government was concerned with stimulating the construction-based economy by indicating a targeted amount of housing construction. The Five-Year Housing Construction Plan system thus corresponded to developmental state policy.

There have been various attempts to analyze Japan's housing system in comparison with its western counterparts. Esping-Andersen (1997) drew on his own welfare-state typology (Esping-Andersen 1990) to suggest that Japan's case is a hybrid of liberal and conservative regimes, implying the lack of social democratic aspects in its welfare system. As Harada(1985) and Ohmoto (1985) among others have pointed out, the state of Japan, which has never set out to expand the social housing sector nor accepted the concept of universal social rights for housing, has completely differed from the European welfare states in terms of providing housing welfare. Through a cross-national comparison of housing policies, Kemeny(1995) suggested a division of rental housing policies according to a unitary and a dualist model. The unitary model has mainly appeared in European countries, where diverse social rented housing has been integrated into the whole rental market. In contrast, the dualist model has been dominant in Anglo-Saxon countries, where the provision of residualized public housing has been separated from the private rental market. Japan's housing policy has largely coincided with the dualist model. A complete consensus on the characteristics of the Japanese housing system remains unseen. Compared to European countries, however, Japan has apparently placed more importance on the owner-occupied housing sector and less on the rented housing sector.

Since the 1970s, the Japanese government further shifted housing policy towards mass-construction of owner-occupied housing to stimulate the economy, putting more stress on encouraging people to acquire their own houses with a loan provided by the GHLC. Thus, greater numbers of GHLC mortgages were granted when the economy became stagnant after the first oil crisis in the early 1970s, after the second oil crisis in the late $1970 \mathrm{~s}$, after the beginning of the recession related to the Plaza Accord in 1985, and after the bubble collapsed in the early 1990s. As housing policy was geared towards further emphasizing 
GHLC loans, public housing policy was marginalized even more. The new starts to public housing, which had increased until the end of the 1960s, have been dropping almost continuously since the beginning of the 1970s. The contrast between the growth of middle-class home ownership and the decline of low-income housing became starker, in terms of operating Japan's housing system.

\section{Neoliberal policy}

Since the late 20th century, Japan's housing system has been radically reorganized to align with neoliberal policy, expanding the market economy in providing housing and mortgages (Hirayama, 2010a). In Japan, as in many other advanced economies, the sphere of housing has been the main target of liberalization. As Torgersen(1987) suggested, housing has been positioned as a 'wobbly pillar' of social policy, because compared with education, health care and social security, housing is much more likely to be provided in the market domain. Housing systems have thus been particularly vulnerable to ideological transformations and have been at the forefront of policy shifts.

Compared to western countries, particularly those that are Anglo-Saxon, the introduction of neoliberal policies in Japan has been especially slow (Forrest \& Hirayama, 2009). While the liberalization of policy started in the early 1980s in Britain and the U.S., Japan's version of neoliberal policy did not begin to emerge until the mid-1990s. In Japan, the LDP, along with government bureaucrats, had played a key role in controlling developmental state policy. Therefore, the radical employment of neoliberal policy by the LDP might have meant an attack on itself, generating a contradiction within its political base. Moreover, unlike the economies of western countries that had experienced prolonged recession since the oil crisis in the early 1970s, Japan's economy had maintained relatively strong performance until the bubble burst. This accounted for the delay in reorganizing policy. With longstanding stagnation after the bubble period, however, the perceived crisis in the developmental state began to fuel the reorientation of policy. In September 2009, the party in power eventually changed from the LDP to the Democratic Party of Japan (DPJ). The new DPJ administration maintained the basic course of policy liberalizing the market economy that the LDP had adopted.

In line with employing a neoliberal course, the government started to reduce the supply of GHLC loans in the mid-1990s and the corporation was ultimately abolished in 2007 . The dissolution of the state agency, which had constituted the core of the housing system, was a particularly important watershed in the postwar history of Japan's housing policy. The large vacancy in the housing loan market created by the abolition of the GHLC was swiftly filled with the expansion of mortgages supplied by private banks. The Housing and Urban Development Corporation was reorganized into the Urban Development Corporation in 1999 and again into the Urban Renaissance Agency in 2004. The new agency substantially reduced its housing programmes. In terms of low-income public housing, new starts, which had been on the decrease, came to an almost complete halt in the 2000s. The Housing Construction Plan Law that had provided a foundation for housing policy was discontinued in 2005. This was followed by the 2006 enactment of the Housing and Livelihood Basic Law, which redefined the roles played by the government and private sector in operating a new housing system oriented towards a more liberalized market economy.

Since the bubble burst, continued economic decline has undermined the security of housing and, thus, the government has been pressed to form a housing safety net system for those who cannot access adequate, affordable housing in the competitive sphere of the market. This led to the 2007 enactment of the Housing Safety Net Law. However, the adoption of a neoliberal course in formulating policy has meant that the government has only sought to construct a minimal housing safety net (Hirayama, 2010b). The principal measure for forming the housing safety net is providing low-income public housing. However, the number of available public rented dwellings has been significantly limited. The government has sought to reinforce the housing safety net by implementing new housing programmes that reach beyond the supply of low-income public housing, which has, for example, encouraged owners of private rental properties to accept older people with low incomes as their tenants. Nonetheless, the scale of these new programmes has been very small. Essentially, housing policies have been contradictory; the government has had no choice but to construct a housing safety net for those who are not able to enter the housing market, but has at the same time restricted the coverage of the housing safety net to expand market-based housing.

Many developed countries have reshaped their housing systems by reducing government assistance to social rented housing sectors (Fitzpatrick \& Stephens, 2008; Whitehead, 2003). However, neoliberalization's impact on housing conditions has differed according to the policy trajectory of individual countries. Even if new construction of low-income housing is reduced, the supply of social rented housing built in the past plays a significant role in providing housing opportunities to low-income people in the present and future. Up until the 1960s, many European countries that employed the unitary model in formulating rental housing policies built a large number of social rented dwellings consisting not only of public housing owned by the government sector but also low-rent housing provided by non-profit organizations and subsidized private rental housing (Balchin, 1996). Despite neoliberalization, these countries still maintain a considerable quantity of social rented housing. In contrast, in Japan, which has adopted the dualist model, the social rented housing sector, which had consisted almost exclusively of housing owned by the public sector and been historically marginalized, has been further residualized by neoliberal policy. Moreover, unlike many 
European countries where governments have operated rental allowance systems (Kemp, 2007), the Japanese government has never framed a rental subsidy scheme. Thus, Japan's low-income housing has been particularly residualized compared to other developed countries.

\section{Decline in low-rent housing}

\subsection{Re-examining its components}

Neoliberal policy in various countries including Japan has accelerated a reduction in the supply of low-rent housing that is available to low-income households. However, the way in which low-rent housing is provided has differed between countries and, thus, the impact of neoliberal policy on housing spheres has also varied. This section looks at the low-rent housing system that is unique to Japan and its neoliberal transformations.

There is a tacit assumption that affordable housing for low-income households is provided almost exclusively in the form of 'decommodified' social housing outside the market sphere. In reality, however, decommodified housing is not necessarily limited to social housing and, moreover, low-rent housing may be supplied within the market domain. Particularly in countries like Japan where social housing is extremely residual, some other types of housing have been assumed to supplement the supply of low-income housing. Therefore, the concept of a low-rent housing sector is worth re-examining and it is important to carefully re-explore elements that comprise the area of low-rent housing to understand how housing is provided to low-income households.

While low-income public housing has been marginalized in Japan, corporate-based employee housing has supplemented the decommodified housing sector and some low-rent housing has been supplied within the sphere of the private market. The provision of corporate-based housing and low-rent private housing has enabled the government sector to avoid having to construct public housing that is sufficient to meet the housing needs of low-income groups. With the ascendance of neoliberal policy, however, the overall mechanisms for providing low-rent housing have begun to unravel. It is thus necessary to not only look at public housing but also employee housing and low-rent private housing in investigating transformations in Japan's low-income housing system.

\subsection{Low-income public housing}

There has been a significant decline in low-income public housing due to the combination of traditional residualization and more recent neoliberalization. The Public Housing Act was enacted in 1951 for 'low income people with housing difficulties'. However, as housing policy has been biased towards expanding middle-class home ownership, public housing has played a limited role in the housing system (Hirayama, 2003; 2007). The income criteria for moving into public housing have progressively narrowed to systematically residualize public housing. At the time of the 1951 Public Housing Act, the majority of households, or the lowest $80 \%$ of all income groups, qualified for public housing. However, the percentage dropped to $33 \%$ in the 1970 s and to $25 \%$ after amendments to the Act in 1996. In addition, a series of discriminatory measures in relation to households whose incomes rose after they moved into public housing have developed. The 1959 amendments established a system in which households with incomes that exceeded a certain amount were required to make efforts to leave, and the 1969 amendment made it possible for local governments to formally ask those on higher incomes to vacate public housing.

When neoliberal policy was introduced in 1990s to reorganize the housing system, public housing became characterized as 'welfare housing' (Hirayama, 2010b). Neoliberal policy has focused on labour market participation rather than public assistance in addressing social issues pertaining to the economic conditions of low-income people (Saunders, 2005). In line with this, the Japanese housing safety net system has targeted a limited number of those regarded as unable to enter the labour force. This has been based on the assumption that employable people can and should secure housing within the framework of the market economy. Therefore, the government has reinforced the tendency of public housing to more narrowly target specific groups that coincide with 'welfare categories', including 'elderly people', 'single-parent households' and 'those with disabilities'. The targets of public housing are no longer all 'low income people with housing difficulties', but have been limited to 'welfare category households' within that group. It has become increasingly difficult to qualify for moving into public housing simply by being a low-income earner.

Within the framework of Japan's postwar home-ownershiporiented housing policy, many people have ascended the housing ladder from rented housing to owner-occupied housing, which has expanded into the mainstream of society (Hirayama, 2003, 2007). Until the 1960s, public housing was aimed at young households on lower-incomes, and they were expected to move out of public housing after a short period and acquire their own housing as their incomes increased. Within this context, public housing was a step on the housing ladder that eventually led to the social mainstream. In the 1970s, however, the government began to separate public housing from mainstream society. Public housing, which has been removed from the housing ladder, has increasingly functioned as an isolated domain where the classes with the lowest-income live indefinitely. The separation between public housing as 'welfare housing' and mainstream society has intensified since the 1990s, with progress in implementing neoliberal policy.

\subsection{Employee housing}

Unique to Japan is that the corporate sector has played a role in supplementing the housing system. Japan has been characterized 
as a 'company society' in which the government has supported security of employment and the provision of corporate-based welfare with regulatory measures and tax incentives (Fujita \& Shionoya, 1997). Many companies adopted a lifelong employment system and a seniority system for wages and promotion, which provided a model of the 'company as a family'. Within the framework of the 'company society' system, the corporate sector has provided employees with a variety of occupational welfare, including housing welfare (Sato, 2007). Major corporations have implemented in-house systems to support their young employees in securing housing, involving low-rent dormitories for single employees and low-rent employee housing for married employees and their household members. In terms of operating an employee housing system, there was the premise that young employees on lower incomes would move out of employee housing and enter the home ownership sector as their incomes increased with advancing age. Corporate-based housing welfare, which is targeted at specific corporation members, cannot compose a 'social' housing sector. However, employee housing, along with public housing, has constituted a 'decommodified' housing sector, supplementing the system of providing low-rent housing.

Nevertheless, the post-bubble recession eroded the economic foundations of corporate-based welfare, resulting in a decrease in the supply of employee housing. Moreover, neoliberal prescriptions have provoked the 'casualization' of the labour market. With the long period of stagnation, increasing numbers of corporations began abandoning the system of lifelong employment and introduced a performance-based system to replace the seniority system. In addition, major amendments to the Dispatched Labour Law (governing employees recruited from agencies) in 1999 and 2003 played a significant role in promoting casual employment. The labour market has therefore been reoriented around declining stability in employment with associated sharp increases in the number of short-term contracts, part-time workers, and temporary employees. The provision of employee housing, which was instrumental in recruiting young people as longtime employees, corresponded to the lifetime employment system. Conversely, the 'casualization' of employment practices has implied the decreased necessity for corporations to provide housing welfare.

\subsection{Low-rent private housing}

Many 'non-professional' property owners in Japan's private rented housing market have characteristically managed low-rent dwellings. Although providing private rented housing has not been particularly profitable, many individuals or families who hold land have constructed rented housing as a sideline without having to invest in site acquisition (Morimoto, 1994). This has made the supply of low-rent housing possible. The rents of multifamily housing in wooden structures have been set at particularly low levels. While dwellings of this type have mostly been substandard in terms of floor area and amenities, they have functioned as low-cost shelters for low-income renters to live in.
Until the 1990s, along with rapid urbanization, many young, low-income individuals and households that flocked into large cities were absorbed in the low-rent private housing market. This made it possible for the government to evade housing responsibilities by substituting private rented housing for public housing.

However, the number of existing low-rent private rental dwellings has been decreasing due to structural ageing or dilapidation. Most owners of low-rent properties had neither the financial ability nor intention to invest in material maintenance or improvements because of low profitability. This accelerated the decrease in low-rent properties. Furthermore, the government began to restructure the private rented housing market in alignment with neoliberal policy in the late 1990s. The intention was to 'modernize' the system of providing and financing rental housing while establishing a more 'professional' and profitable market for investments in private rented housing. This led to major amendments to the Housing Lease Act in 1999. Before this amendment, tenants' security of tenure was protected and thus landlords could not easily evict them. However, with this amendment, it is now possible for owners to rent their houses for more limited periods and thus more accurately calculate their prospects of making profits. The government has also sought to establish a rental-property-security market. This requires yields from security investments to be more predictable. As a consequence of the new policy to modernize the private rented housing sector, low-rent dwellings provided by non-professional landlords are declining while higher-rent dwellings financed by more professional investors are on the increase.

\section{Undermined housing security}

What then are the consequences of neoliberal prescriptions in the area of low-income housing? This last section explores transformations in housing circumstances surrounding low-income groups. Housing policy in postwar Japan has inclined towards promoting middle-class home ownership while residualizing low-income rented housing. This tenure-discriminatory policy was based on the assumption that the large majority of households would be able to ascend the housing ladder towards achieving property ownership. Thus, the expansion of middle-class home ownership was considered to justify the marginality of rental housing policy. Since the bubble burst, however, Japan has long been in the grip of a deep recession. In response to this, neoliberal thought was introduced to formulate policy with expectations of stimulating economic recovery. This was reflected in re-directing housing policy towards emphasizing the role of the market in supplying housing. Nevertheless, the economy has continued to decline and housing security for low-income people has been undermined. With deepening stagnation, the traditional system of facilitating home ownership began to unravel, making it more difficult for many households to enter the owner-occupied 
Annual income

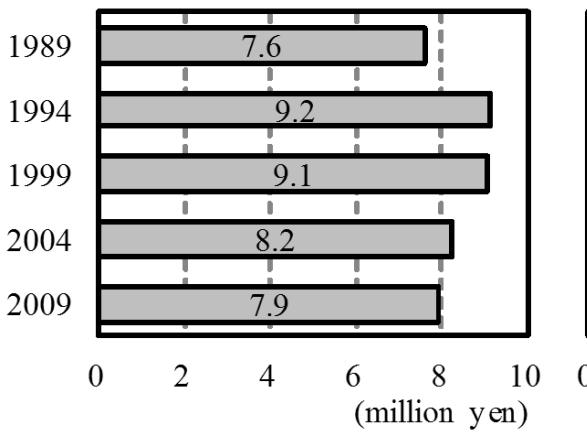

Monthly mortgage repayments

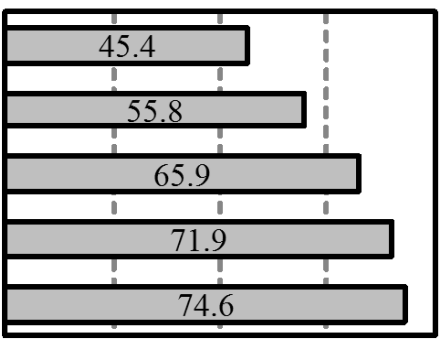

20

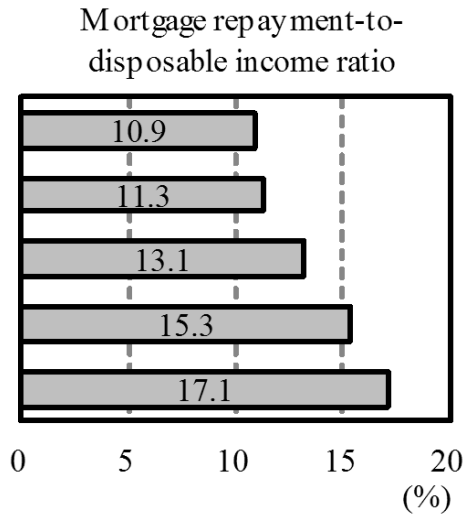

Note: Data are for households with two or more members.

Source: National Survey of Family Income and Expenditure.

Fig. 1. Changes in Economic Situations of Owner-occupier Households with Mortgage Debts

housing sector. This has inevitably led to the expansion of demand for rented housing and increasing numbers of low-income households that strongly aspire to occupy low-rent dwellings. Neoliberal policy, however, has further marginalized the system of providing low-income housing, resulting in increased housing insecurity.

Within the context of the post-bubble recession, the overall economy became deflationary and consequently the economic pillars of home ownership began to disintegrate (Hirayama, 2010a). The prices of land and housing have dropped since the bubble collapsed. Nevertheless, the economic burdens imposed by accessing and maintaining home ownership have become heavier. According to Figure 1 that shows economic changes in owner-occupiers of mortgaged housing, a decrease in incomes combined with an increase in outstanding mortgage debts has resulted in a heavier burden from mortgage repayments. This implies that the decline in incomes has translated into smaller deposits and therefore larger mortgage liabilities. The average nominal annual income of owners of mortgaged houses increased from 7.6 million yen in 1989 to 9.2 million yen in 1994 but then decreased to 7.9 million yen in 2009. The average monthly mortgage repayments of the same group continued to increase from 45,400 yen in 1989 to 74,600 yen in 2009. Consequently, between 1989 and 2009, average mortgage-to-disposable income ratios for mortgaged house owners continued to rise from 10.9 per cent to 17.1 per cent.

As many households have faced difficulties with entering the home ownership market, demand for rented housing has expanded. The continued implementation of neoliberal policy, however, has led to a substantial decrease in the availability of low-rent dwellings (Hirayama, 2010a). New construction of low-income public housing has almost halted and, moreover, reconstruction of public housing developments has tended to result in a reduced number of dwellings. This has led to a decline in the overall supply of public housing. The Urban Renaissance
Agency has also begun to dispose of a number of rental properties. Thus, the number of public rented dwellings, including both low-income public dwellings and public corporation dwellings, decreased from 3,120,000 in 2003 to 3,010,000 in 2008. With the weakening of the 'company society' system, many corporations have begun to unload considerable numbers of properties previously used for employee housing. The amount of employee housing, which was 2,050,000 in 1993, decreased to $1,400,000$ in 2008. Consequently, the availability of 'decommodified' housing has been significantly reduced. The ratio of public rented housing plus employee housing against all rented housing dropped from 31 per cent in 1993 to 25 per cent in 2008. The number of low-rent properties in the private rental housing market has been on the decrease. Private rented multi-family dwellings of wooden structures, which are low quality but have low rents, accounted for 24 per cent of all rented housing in 1993. The figure had decreased to 13 per cent by 2008 .

As seen in Figure 2, changes to the economic conditions of renters have been characterized by a combination of decreased nominal incomes, increased nominal rents and thus increased burdens imposed by rent payments. Since the bubble burst, the stagnated economy has continued to be deflationary. This has been reflected in the fact that the average nominal annual income of renters decreased from 6.3 million yen in 1994 to 5.6 million yen in 2009. The average nominal monthly rent, which was 29,800 yen in 1989 , rose to 50,500 yen in 2009 . The deflationary economy and the decrease in incomes might have been expected to encourage a drop in market rents. Nevertheless, real rent levels have continued to rise. The main factor behind this is the reduced availability of low-rent housing. As a result, the average rent-to-income ratio continuously increased from 9.6 per cent in 1989 to 15.1 per cent in 2009.

Decline in the availability of low-rent housing has combined with the 'casualization' of the employment market to create a new housing crisis characterized by an increase in the number of 

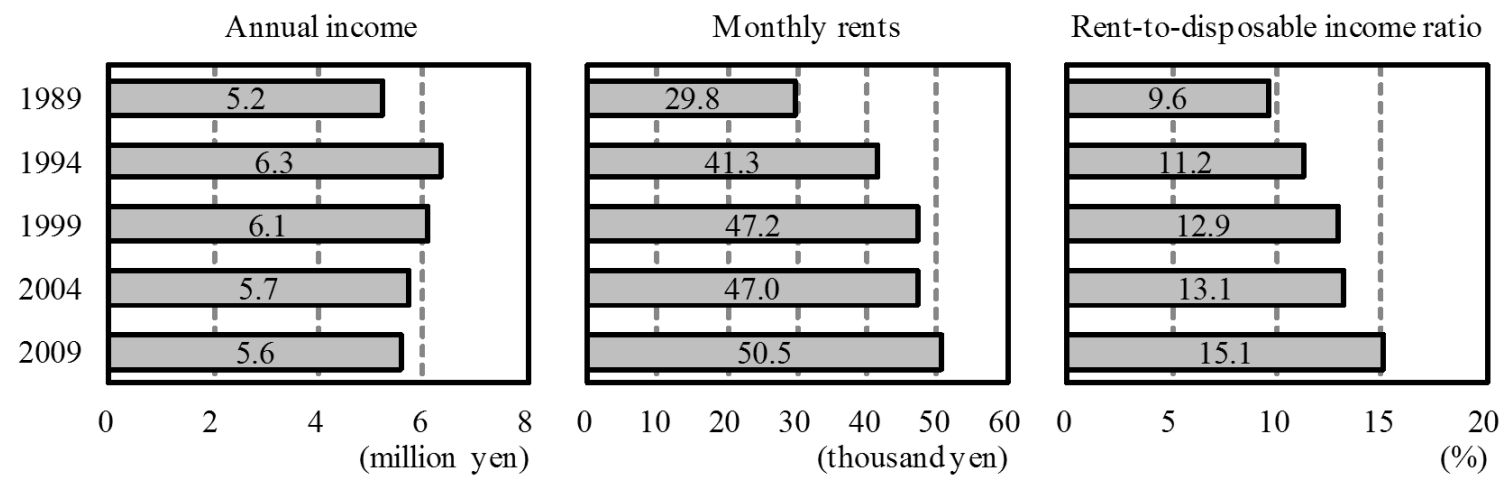

Note: Data are for households with two or more members.

Source: National Survey of Family Income and Expenditure.

Fig. 2. Changes in Economic Situations of Renter Households

people who lost both employment and housing (Hirayama, 2010b). Many manual workers who had lived in company dormitories were laid off, resulting in an increase in those who both lost jobs and dwellings simultaneously. Increasing numbers of renters in the private rental housing market have been unable to pay their rent largely due to job losses. Consequently, the forcible eviction of renters who are in arrears by landlords and rent guarantor firms has generated a new social problem.

In response to the housing crisis, the government began to launch a series of emergency housing measures to cope with displaced workers in the late 2000s. This involved, for example, temporarily providing rental allowances and various loans to finance living expenses. These emergency housing measures, meant to benefit displaced workers for limited periods, were designed to encourage workers to return to the labour market and, subsequently, the housing market. This corresponded with the neoliberal principle accentuating the importance of participation in the labour market. The government has characterized the set of emergency housing programmes as a 'trampoline-style second safety net'. The concept was to build a 'second safety net' that, added to the 'first safety net' of the unemployment insurance system, would act as a 'trampoline' by helping to bounce displaced workers back into the labour market. Ideally, this would prevent workers from relying on public assistance as their 'last safety net'. With the spread of the housing crisis, the number of households wishing to move into public housing soared rapidly. However, there were few public rental dwellings available and the government hoped the 'second safety net' would help people return to the labour and then the housing market.

However, emergency housing measures have not significantly been effective in securing dwellings. The expansion of neoliberal policy has been accompanied by a cycle in which the liberalization of market forces has translated into a more precarious market. With the 'casualization' of the labour force, laid-off workers cannot necessarily find employment opportunities, and, even if they do return to the labour market, they cannot necessarily earn sufficient wages to access the housing market. Moreover, as has been discussed, there has been a decrease in the supply of low-rent housing. Even when displaced workers do re-enter the labour market, it has progressively become more difficult for them to secure affordable places to live because of transformations in the housing market. The decline in the availability of low-rent housing has critically undermined the effectiveness of emergency housing measures.

\section{Conclusion}

Neoliberalism in many developed countries has effectively reorganized housing systems towards expanding market economies, resulting in a decline in social rented housing sectors. However, the impact of neoliberalization on housing conditions has been strongly differentiated according to the housing situation when the policy shift began to take place. In many European countries, even after neoliberal policy began to affect the organization of housing systems, the large accumulated supply of social rented housing, along with the development of rent allowance systems, played a significant role in providing low-income people with housing. In contrast, Japan's postwar housing policy has consistently placed importance on the expansion of middle-class home ownership while the public rented housing sector has been residual and no rent subsidy systems have existed. This deficiency has combined with neoliberal policy to even further marginalize low-income housing. In Japan, not only public housing but also employee housing and some private rented housing have comprised the low-rent housing sector. Along with neoliberalization, however, the overall system of providing housing at low rents has progressively disintegrated. Of all developed countries, Japan's housing safety net system has been particularly flimsy.

The preceding analysis in this article suggests a new question as to whether or not the consequences of neoliberal policies will lead to reshaped housing systems. Neoliberal policy in Japan has combined with the extraordinarily prolonged economic decline to 
produce a new housing crisis. The housing system that was oriented towards home ownership was assumed to enable the government to evade providing a substantial number of dwellings to low-income households. Within the context of the post-bubble economic decline, however, increasing numbers of households have despaired in attaining home ownership and have thus entered the rented housing market. Nevertheless, neoliberal policy has begun to unravel the low-rent housing system. There have been continuous decreases in affordable housing in both the home ownership and rental markets. It is thus likely that the Japanese government will be pressed to reconsider the organization of housing policy and improve not only the conditions of the owner-occupied housing sector but also the rented housing sector. It is not certain at this point whether the Japanese government will undertake a substantial restructuring of housing policy beyond neoliberalism. What is certain is that the current, residualized low-income housing system will not successfully overcome the housing crisis.

\section{References}

1. Abe, M. (2001), Jutaku seisaku niokeru jititai no yakuwari [the role of municipalities in housing policy], in S. Harada (ed), Nihon no Toshi Hou: vol. 2 [Japan's Urban Laws vol. 2], 299-320, Tokyo: Tokyo University Press.

2. Balchin, P. (ed) (1996), Housing policy in Europe, London: Routledge.

3. Esping-Andersen, G. (1990), The Three Worlds of Welfare Capitalism, Cambridge: Polity Press.

4. Esping-Andersen, G. (1997), "Hybrid or unique? the Japanese welfare state between Europe and America", Journal of European Social Policy, 7(3): 179 189.

5. Fitzpatrick, S. and M. Stephens (eds) (2008), The Future of Social Housing. London: Shelter.

6. Forrest, R. and Y. Hirayama (2009), The uneven impact of neo-liberalism on housing opportunities, International Journal of Urban and Regional Research, 33(4): 998 1013.

7. Fujita, Y. and Y. Shionoya (eds) (1997), Kigyo nai Fukushi to Shakai Hosho [Employee Benefits and Social Security], Tokyo: Tokyo University Press.

8. Harada, S. (1985), Sengo jutaku housei no seiritsu katei [The establishment process of housing laws in postwar Japan], in Institute of Social Science, Tokyo University (ed) Fukushi Kokka vol. 6: Nihon no Shakai to Fukushi [The Welfare State vol. 6:
Japanese Society and Welfare]. Tokyo: Tokyo University Press.

9. Hayakawa, K. (2002), Japan, in M. A. Agus, J. Doling, and D. Lee (eds) Housing Policy Systems in South and East Asia, 20 37, Houndmills: Palgrave Macmillan.

10. Hirayama, Y. (2003), Housing and social inequality in Japan, in $M$. Izuhara (ed), Comparing Social Policies: Exploring New Perspectives in Britain and Japan, 151 171, Bristol: Polity Press.

11. Hirayama, Y. (2007), Housing and state strategy in post-war Japan, in R. Groves, A. Murie \& C. Watson (eds), Housing and the New Welfare State: Perspectives from East Asia and Europe, $101 \sim 126$, Aldershot: Ashgate.

12. Hirayama, Y. (2010a), "Housing pathway divergence in Japan's insecure economy", Housing Studies, 25(6): 777 797.

13. Hirayama, Y. (2010b), "Neoliberal policy and the housing safety net in Japan", City, Culture and Society, 1(3): 119 126.

14. Kemeny, J. (1995), From Public Housing to the Social Market: Rental Policy Strategies in Comparative Perspective, London: Routledge.

15. Kemp, P. (Ed.) (2007), Housing Allowances in Comparative Perspective, Bristol: Policy Press.

16. Morimoto, N. (1994), Toshi Kyoju to Chintai Jutaku [Urban Rental Housing], Kyoto: Gakugei Shuppansha.

17. Ohmoto, K. (1985), Fukushi kokka to wagakuni jutaku seisaku no tenkai [The welfare state and housing policy in Japan], in Institute of Social Science, Tokyo University (ed) Fukushi Kokka vol. 6: Nihon no Shakai to Fukushi [The Welfare State vol. 6: Japanese Society and Welfare], Tokyo: Tokyo University Press.

18. Ohmoto, K. (1996), "Kyoju seisaku no gendai shi [modern history of housing policy]", in K. Ohmoto and M. Kaino (eds), Gendai Kyoju: Rekishi to Shiso [Housing Policy: History and Ideology], 8 9 120, Tokyo: Tokyo University Press.

19. Sato, I. (2007), Welfare regime theories and the Japanese housing system, in Y. Hirayama and R. Ronald (eds), Housing and Social Transition in Japan, 73 93, London: Routledge.

20. Saunders, P. (2005), Welfare to Work in Practice: Social Security and Participation in Economic and Social Life, Aldershot: Ashgate.

21. Torgersen, U. (1987), Housing: the wobbly pillar under the welfare state, in B. Turner, J. Kemeny and L. Lundqvist (eds), Between State and Market: Housing in the Post-Industrial Era, Stockholm: Almqvist \&Wiksell International.

22. Whitehead, C. (2003), Restructuring social housing systems, in R. Forrest \& J. Lee (eds) Housing and Social Change: East-West perspectives, 46-68, London: Routledge. 